\title{
Microbiological Profile of the Traditionally Collected Industrial Raw Milk from the Milk Pocket Zones of Bangladesh
}

\author{
Gouranga C Chanda ${ }^{1}$, Gazi M Noor Uddin², Aparna Deb ${ }^{3}$,Tahmina Bilkis², Sharmin Chowdhury ${ }^{4}$ and M Basir \\ $\operatorname{Uddin}^{5}$ \\ ${ }^{1}$ Chittagong Veterinary \& Animal Sciences University, Khulsi, Chittagong 4202, Bangladesh, ${ }^{2}$ Departrment of Dairy \& Poultry Science, Chittagong \\ Veterinary \& Animal Sciences University, Khulsi, Chittagong 4202, Bangladesh, ${ }^{3}$ Youth Training Centre, Halishahar Housing Estate (Baropool), \\ Chittagong 4216, Bangladesh, ${ }^{4}$ Department of Pathology \& Parasitology, Chittagong Veterinary \& Animal Sciences University, Khulsi, Chittagong \\ 4202, Bangladesh, ${ }^{5}$ Pals Agrovet, 89-90 Agrabad C/A, Chittagong 4100, Bangladesh
}

\section{[Received 18 August 2007; Accepted 14 June 2008]}

\begin{abstract}
The study was aimed to evaluate the bacteriological profile of the traditionally collected industrial raw milk from the milk pocket zones of Bangladesh. About 365 raw milk samples were collected from the milk tanker, who brought raw milk from the mother chilling centre where raw milk was chilled at $4^{\circ} \mathrm{C}$ following traditional method. All milk samples were subjected to perform standard plate count and total coliform count. The average standard plate count was found to be $4.37 \times 10^{6} \mathrm{cfu} / \mathrm{ml}$ and the highest occurrence of standard plate count was found to be $6.70 \times 10^{6} \mathrm{cfu} / \mathrm{ml}$ in October and the lowest $\left(3.28 \times 10^{6} \mathrm{cfu} / \mathrm{ml}\right)$ in March. The highest occurrence of total viable bacteria was found to be $5.64 \times 10^{6} \mathrm{cfu} / \mathrm{ml}$ in autumn and the lowest was found to be $3.78 \times 10^{6} \mathrm{cfu} / \mathrm{ml}$ in summer. On the other hand, the average of the coliform bacterial count was found to be $3.88 \times 10^{5} \mathrm{cfu} / \mathrm{ml}$ with the highest $\left(5.70 \times 10^{5} \mathrm{cfu} / \mathrm{ml}\right)$ occurrence in May and the lowest $\left(1.90 \times 10^{5} \mathrm{cfu} / \mathrm{ml}\right)$ in January. Moreover, the highest occurrence of coliform count was found to be $4.84 \times 10^{5} \mathrm{cfu} / \mathrm{ml}$ in rainy season and the lowest was $2.75 \times 10^{5} \mathrm{cfu} / \mathrm{ml}$ found in winter.
\end{abstract}

\section{Introduction}

Milk is the most popular food for both children and adults. This is due to uniqueness in nutritional constituents like water, fat, protein, lactose, minerals, vitamins and pigments. Considering the nutritional composition, milk is the nature's single most nearly complete food ${ }^{1}$. Milk production started in the world 6,000 years back $^{2}$. In early age, milk was produced and utilized in the limited areas. Now milk production increased to 10 times in the world ${ }^{2}$. With the increase of people's residential area also increase the milk distribution range. And people prefer to have processed milk instead of ordinary milk. Henceforth, industrialization of dairy has got top priority to produce commercial milk and is needed to distribute to long distance from the production area ${ }^{1}$.

Bangladesh is a tropical country with high humidity and heavy rainfall and hence this environment is favourable for the growth and multiplication of bacteria, virus, fungus and parasites. Milk is the lacteal secretion of mammary gland and good media for the growth and multiplication of microbes. This very rich biological product is prone to all types of microbiological contamination ${ }^{3}$. And contamination takes place through various ways such as from the barn, during chilling, during transportation, during processing and during marketing. However, contamination starts from the interior of the udder, then coat of the animals, milker's hand, soil and air of the barn, milking utensils etc. ${ }^{4}$. It was found that fore milk contain higher number of organisms than late milk as microbes enter through the teat canal and lodged in the lining of the inner alveoli and cistern ${ }^{5}$. Soon after collection of raw milk, if it is not chilled properly, psychrophillic and mesophillic bacteria starts to multiply rapidly leading to higher counts ${ }^{6-7}$.

There are so many standards regarding the range of total viable count and coliform bacteria count in different countries and regions such as the American standards, the Indian standards, the Danish standards and the European standards. However, there is paucity of information regarding the bacterial content/load in raw milk in Bangladesh. But the standards of "International Dairy Congress" for total plate count for grade Araw milk is $10,000 \mathrm{cfu} / \mathrm{ml}$, for grade $B$ raw milk is $100,000 \mathrm{cfu} / \mathrm{ml}$ and for grade $C$ raw milk is no limit of total bacterial count. And the coliform count is $10 \mathrm{cfu} / \mathrm{ml}$ for grade A raw milk ${ }^{8}$. With a view to the above facts, present study was carried out to find out the total number of viable bacteria and coliform bacteria in traditionally collected raw milk in the milk pocket area of Bangladesh.

\section{Materials and Methods}

Study area

Baghabari, Bera, Demra and Chatmohar Thana of Pabna district were selected for this study. These areas are knows as milk pocket zone of Bangladesh. Farmers were selected and brought under an agreement that they will supply milk to keep smooth flow of milk to the factory. These areas are covered with Jamuna River, its branches and merged under water up to 4 months in a year. During winter, so many lands of these areas are used as pasture land in 
this period where the cattle and buffaloes are brought under free range system. The farmers were selected and contracted considering the commercial point of view, i.e., suitable and beneficial for the company.

\section{Collection of raw milk from the milk pocket zones}

Raw milk has been collected from this area by Milk Vita and other private dairies like Pran, Arang, Amo, Iglo, Bikrampur Dairy etc. The farmers of this area know better management system of domestic animals than the farmers of the other parts of the country. This is due to better animal healthcare and other technical facilities provided by the Milk Vita and other private dairy industries. However, they fail to maintain standard milking system due to illiteracy, lack of awareness about the prevention of microbial contamination, lack of training about health and hygiene. Milk Vita used to collect milk from its members as this organization runs following cooperative system. But the private dairies used to have milk from the contract farmers who are or are not the member of the Milk Vita. Farmers used to perform milking following traditional method. Then milk is brought to neighbouring chilling sub-centre in the milk-can by travelling around 10 miles by rickshaw or van and sometimes by motor vehicles without any preservatives. Thus, there occurs accumulation of milk from different cows of different farmers' house. It is very surprising and interesting that quality control personnel accept the milk based on organoleptic test and some physicochemical parameters, e.g., colour, flavour, taste, acidity, $\mathrm{pH}$, fat content, specific gravity etc. instead of any microbiological parameter. The price is given based on fat content of raw milk. Then all the collected milk is chilled at $4^{\circ} \mathrm{C}$ immediately in the chilling sub-centre. From the chilling sub-centre, raw milk is brought to the mother chilling centre at Baghabari Ghat where organoleptic tests and other physicochemical tests are performed again. Then the milk is chilled at below $4^{\circ} \mathrm{C}$ at least for $72 \mathrm{~h}$ before delivery to the factory.

\section{Enumeration of total number of viable and coliform bacteria}

For transportation of raw milk from the mother chilling centre to the factory a specially designed tanker is used in which $4^{\circ} \mathrm{C}$ temperature is maintained. Soon after the arrival of milk to the factory, the milk is received based on organoleptic tests and other necessary physicochemical tests. Raw milk samples were collected aseptically from the tanker for microbiological tests. In this study 365 raw milk samples (one in every day for whole one year) were collected and tested throughout the year. All of the samples were subjected to perform standard plate count for total number of viable bacteria and coliform count for the enteric bacteria. All of the tests were performed according to the standard methods for the examination of dairy products according to American Association of Public Health (APHA) ${ }^{8}$. The tests were repeated three times for reproducibility and accuracy.

\section{Results and Discussion}

Commercial milk production has got top priority and it is increasing day-by-day. Today, so many private dairy industries are being run and taking a leading role in milk collection, processing and marketing throughout the country. Though milk is collected based on some physicochemical parameters such as fat content, acidity, $\mathrm{pH}$, specific gravity and the price of milk is paid based on fat content rather than the microbiological parameters. Microbiological parameters are important for the shelf-life of the product $^{9}$. Milk with lower count of microbes can be achieved by aseptic or sterile milk collection ${ }^{10-11}$.

The results of the present study show that the average of total viable count varied between $3.28 \times 10^{6} \mathrm{cfu} / \mathrm{ml}$ in March and $6.7 \times 10^{6}$ $\mathrm{cfu} / \mathrm{ml}$ in October (Table 1). The overall occurrence of total viable count was found to be $4.37 \times 10^{6} \mathrm{cfu} / \mathrm{ml}$. Season-wise distribution of bacterial load in raw milk is shown in Table 2. The highest occurrence was found to be $5.64 \times 10^{6} \mathrm{cfu} / \mathrm{ml}$ in autumn and the lowest was found to be $3.77 \times 10^{6} \mathrm{cfu} / \mathrm{ml}$ in summer (Table 2).

Table 1. Monthly occurrence of total viable count in raw milk

\begin{tabular}{lcc}
\hline Month & $\begin{array}{c}\text { Total viable count } \\
(\mathrm{cfu} / \mathrm{ml})\end{array}$ & $\begin{array}{c}\text { Mean } \pm \text { SD } \\
(\mathrm{cfu} / \mathrm{ml})\end{array}$ \\
\hline January & $3.30 \times 10^{6}$ & $3.30 \times 10^{6} \pm 790,753$ \\
February & $3.50 \times 10^{6}$ & $3.53 \times 10^{6} \pm 6,592$ \\
March & $3.28 \times 10^{6}$ & $3.28 \times 10^{6} \pm 695,221$ \\
April & $4.06 \times 10^{6}$ & $4.06 \times 10^{6} \pm 57,127$ \\
May & $3.99 \times 10^{6}$ & $3.99 \times 10^{6} \pm 429,885$ \\
June & $3.80 \times 10^{6}$ & $3.81 \times 10^{6} \pm 758,294$ \\
July & $4.57 \times 10^{6}$ & $4.57 \times 10^{6} \pm 759,909$ \\
August & $4.19 \times 10^{6}$ & $4.19 \times 10^{6} \pm 743,632$ \\
September & $4.64 \times 10^{6}$ & $4.64 \times 10^{6} \pm 183,873$ \\
October & $6.70 \times 10^{6}$ & $6.70 \times 10^{6} \pm 1,925,381$ \\
November & $5.60 \times 10^{6}$ & $5.60 \times 10^{6} \pm 131,129$ \\
December & $4.81 \times 10^{6}$ & $4.80 \times 10^{6} \pm 1,529,546$ \\
Yearly average count & $4.37 \times 10^{6}$ & $4.37 \times 10^{6} \pm 1,015,744$ \\
(cfu/ml) & & \\
\hline
\end{tabular}

Table 2. Season variation of total viable bacterial count in raw milk

\begin{tabular}{lcc}
\hline Season & $\begin{array}{c}\text { Total viable count } \\
(\mathrm{cfu} / \mathrm{ml})\end{array}$ & $\begin{array}{c}\text { Mean } \pm \text { SD } \\
(\mathrm{cfu} / \mathrm{ml})\end{array}$ \\
\hline $\begin{array}{l}\text { Winter } \\
\text { (December-February) }\end{array}$ & $3.88 \times 10^{6}$ & $3.88 \times 10^{6} \pm 1,336,450$ \\
$\begin{array}{l}\text { Summer } \\
\quad \text { (March-May) }\end{array}$ & $3.78 \times 10^{6}$ & $3.77 \times 10^{6} \pm 835,548.3$ \\
$\begin{array}{l}\text { Rainy } \\
\quad \text { (June-August) }\end{array}$ & $4.19 \times 10^{6}$ & $4.87 \times 10^{6} \pm 808,098.1$ \\
$\begin{array}{l}\text { Autumn } \\
\quad \text { (September-November) }\end{array}$ & $5.64 \times 10^{6}$ & $5.64 \times 10^{6} \pm 2,004,106$ \\
$\begin{array}{l}\text { Yearly average count } \\
\text { (cfu/ml) }\end{array}$ & $4.37 \times 10^{6}$ & $4.37 \times 10^{6} \pm 1,015,744$ \\
\hline
\end{tabular}

The results of the present study revealed that the total viable count is much higher due to disease of the udder of the animals, other diseases that shed organisms through natural excreta, environmental factors like high humidity, heavy rainfall, interior of the udder, coat of the animals, utensils, milker's hand, soil, air barns, during handling, transportation, incomplete or inefficient clean-inplace (CIP), processing etc. ${ }^{12-15}$. Milk collection with no consideration of asepsis leads to higher number of bacterial count in raw milk ${ }^{10-11}$. Not only that, the present count in traditionally collected industrial raw milk is much higher than the American standard $^{16}$, European Union standard ${ }^{17}$ and the Danish standard ${ }^{17}$ (Table 3). However, the bacterial load is similarity to the Indian 
Table 3. Standard of total viable count and total coliform bacterial count in raw milk in different countries/regions

\begin{tabular}{llcl}
\hline $\begin{array}{l}\text { Name of the } \\
\text { country/region }\end{array}$ & Standard plate & Coliform bacterial & Grade/Standard \\
count & 200,000 & Nil & A \\
\hline The USA $^{16}$ & $1,000,000$ & 10 & $\mathrm{~B}$ \\
& No Limit & 100 & $\mathrm{C}$ \\
European Union $^{17}$ & $<100,000$ & Nil & - \\
& - & - & - \\
Denmark $^{17}$ & - & - & - \\
& $<30,000$ & Nil & Extra superior bacteriological quality \\
& $30,000-100,000$ & Nil & Satisfactory bacteriological quality \\
& $100,000-300,000$ & 100 & Less satisfactory bacteriological quality \\
& $300,000-800,000$ & - & Non-satisfactory bacteriological quality \\
& $>800,000$ & - & Very unsatisfactory bacteriological quality \\
India $^{18}$ & Not exceeding 200,000 & Nil & Very good \\
& Between 200,000 and 1,000,000 & - & Good \\
& Between 1,000,000 and 5,000,000 & - & Fair \\
& Over 5,000,000 & - & Poor \\
\hline
\end{tabular}

standard ${ }^{18}$ on the category of 'fair' milk. Considering the monthly occurrence of total viable count seems to be highest in October. This might be due to lack of practice of aseptic milk collection, imperfect chilling system, inefficient or incomplete CIP of milk tankers and improper disinfection of milk utensils ${ }^{19}$. The lowest count was found to be in winter as there is the availability of fellow land during that time where cattle populations are considered to be reared at free range system. In this system, there is less density of cattle population and hence less chance of faecal and environmental contamination of milk during milk collection and transportation ${ }^{20}$. Surprisingly, the highest occurrence of total viable count was found to be in autumn season. This might be due to faulty collection, cleaning, transportation and processing may have a role in giving higher bacterial count in raw milk ${ }^{20}$.

Coliform bacteria were detected in the raw milk samples throughout the year (Table 4). The average of total coliform bacteria was found to be $3.88 \times 10^{5} \mathrm{cfu} / \mathrm{ml}$ with the highest $\left(5.70 \times 10^{5} \mathrm{cfu} / \mathrm{ml}\right)$ occurrence in May and the lowest $\left(2.72 \times 10^{5} \mathrm{cfu} / \mathrm{ml}\right)$ in December (Table 4). The occurrence the total coliform count was maximum $\left(4.84 \times 10^{5} \mathrm{cfu} / \mathrm{ml}\right)$ during the rainy months and minimum $(2.75 \mathrm{x}$ $10^{5} \mathrm{cfu} / \mathrm{ml}$ ) during the winter months (Table 5).

Table 4. Monthly occurrence of coliform bacterial count in raw milk

\begin{tabular}{lcc}
\hline Month & $\begin{array}{c}\text { Total coliform count } \\
(\mathrm{cfu} / \mathrm{ml})\end{array}$ & $\begin{array}{c}\text { Mean } \pm \text { SD } \\
(\mathrm{cfu} / \mathrm{ml})\end{array}$ \\
\hline January & $1.90 \times 10^{5}$ & $1.90 \times 10^{5} \pm 178,478$ \\
February & $3.63 \times 10^{5}$ & $3.63 \times 10^{5} \pm 233,625$ \\
March & $3.38 \times 10^{5}$ & $3.38 \times 10^{5} \pm 202,152$ \\
April & $3.26 \times 10^{5}$ & $3.26 \times 10^{5} \pm 230,497$ \\
May & $5.70 \times 10^{5}$ & $5.70 \times 10^{5} \pm 312,029$ \\
June & $4.24 \times 10^{5}$ & $4.24 \times 10^{5} \pm 267,951$ \\
July & $4.88 \times 10^{5}$ & $4.88 \times 10^{5} \pm 481,759$ \\
August & $5.40 \times 10^{5}$ & $5.40 \times 10^{5} \pm 333,573$ \\
September & $4.76 \times 10^{5}$ & $4.76 \times 10^{5} \pm 347,242$ \\
October & $3.10 \times 10^{5}$ & $3.10 \times 10^{5} \pm 189,675$ \\
November & $3.70 \times 10^{5}$ & $3.70 \times 10^{5} \pm 144,717$ \\
December & $2.72 \times 10^{5}$ & $2.72 \times 10^{5} \pm 103,252$ \\
Yearly average count & $3.88 \times 10^{5}$ & $3.88 \times 10^{5} \pm 209,820$ \\
$\quad$ (cfu/ml) & & \\
\hline
\end{tabular}

Table 5. Seasonal variation of coliform bacterial count in raw milk on the basis of season

\begin{tabular}{lcc}
\hline Season & $\begin{array}{c}\text { Total viable count } \\
(\mathrm{cfu} / \mathrm{ml})\end{array}$ & $\begin{array}{c}\text { Mean } \pm \text { SD } \\
(\mathrm{cfu} / \mathrm{ml})\end{array}$ \\
\hline $\begin{array}{l}\text { Winter } \\
\quad(\text { December-February) }\end{array}$ & $2.75 \times 10^{5}$ & $2.75 \times 10^{5} \pm 191,611.8$ \\
$\begin{array}{l}\text { Summer } \\
\quad \text { (March-May) }\end{array}$ & $4.11 \times 10^{5}$ & $4.11 \times 10^{5} \pm 256,968.2$ \\
$\begin{array}{l}\text { Rainy } \\
\quad \text { June-August) }\end{array}$ & $4.84 \times 10^{5}$ & $4.84 \times 10^{5} \pm 379,578.5$ \\
$\begin{array}{l}\text { Autumn } \\
\quad \text { (September-November) }\end{array}$ & $3.85 \times 10^{5}$ & $3.85 \times 10^{5} \pm 38,911.21$ \\
$\begin{array}{l}\text { Yearly average count } \\
\text { (cfu/ml) }\end{array}$ & $3.88 \times 10^{5}$ & $3.88 \times 10^{5} \pm 209,820$ \\
\hline
\end{tabular}

Presence of single coliform bacteria in raw milk and milk products is the indication of faecal and environmental contamination of bacteria $^{21}$. Much higher count of coliform bacteria was found to be common in industrial raw milk than the standards of the other countries and regions of the world. The coliform bacterial count was found to be highest in rainy season ${ }^{20}$. This might be due to shedding of bacteria in the floor of barn, falling of immunity against diseases of animals, higher density of animals and favourable environment for the growth and multiplication of microbes ${ }^{19}$.

In this study, the highest total count was found in autumn and the lowest in summer, while the highest coliform count was detected in rainy season and the lowest in winter. Bacterial counts show the highest among the standards of the globe, so far found. Coliform count reveals very poor production and handling of milk in this area of Bangladesh. All milk produced in Bangladesh should follow ultra-high temperature (UHT) method. Otherwise this very rich food ingredient may come as one of the principal cause of public health hazard. Dairy farmers should be taken as the target group of awareness creation for safety measure of public health, especially for milk-borne diseases including tuberculosis. 


\section{References}

1. Elder FB. 1953. Sanitary milk control and its relation to the sanitary, nutritive, and other qualities of milk. Am J Public Health Nations Health. 43(8): 1056-1057.

2. OLAM. 2007. Dairy products. Available at: http://www.olamonline. com/htmlDocs/bd_dp.html. Accessed 14 February 2007.

3. Turner GE \& Smith ER. 1941. Sources of hemolytic enterococci found in milk. J Milk Technol. 4: 183-186.

4. Evans AC. 1916. The bacteria of milk freshly drawn from the normal udders. J Infect Dis. 18: 473-476.

5. Faber JE. 1930. A study of the bacterial content of the fore milk of cows. J Dairy Sci. 13: 449-452.

6. Foltys V \& Kirchnerová K. 2006. Mesophilic and psychrotrophic aerobic sporulating microorganisms in raw cow's milk. Archiva Zootechnica. 9: 1-15.

7. Meer RR, Baker J, Bodyfelt FW \& Griffiths MW. 1991. Psychrotrophic Bacillus spp. in fluid milk products - A review. J Food Prot. 54: 969-979.

8. Wehr HM \& Frank JH. 2004. Standard Methods for the Examination of Dairy Products, $17^{\text {th }}$ edn. American Public Health Association (APHA) Publications Marketing, Washington DC.

9. Murphy SC. 2007. Shelf-life of fluid milk products - Microbial spoilage: The evaluation of shelf-life. Available at: http://www.foodscience. cornell.edu/cals/foodsci/extension/upload/Bact-Milk-Shelf-LifeDoc.doc. Accessed 14 February 2007.

10. Dahlberg AC, Kosikowsky FV, Seeley HW \& Leventhal AA. 1950. The sanitizing of milk machines. J Milk Food Technol. 13: 5-18.
11. Dahlberg AC, Adams HS \& Held EIE. 1953. Sanitary Milk Control and Its Relation to the Sanitary, Nutritive and Other Qualities of Milk. National Academy of Sciences, National Research Council, Washington DC.

12. Terplan G \& Weisner HV. 1970. Microbiological quality of liquid milk. Dairy Sci Abst. 27: 516-521.

13. Patel DA, Siva CV \& Sannabhadti SS. 1993. Sources of microbial contamination of raw milk. Ind J Dairy Sci. 46: 67-70.

14. Wadud A, Ali MK, Kober AKHM, Islam MN \& Debnath GK. 2002. Physical, chemical and microbiological qualities of buffaloes milk. Bangladesh J Anim Sci. 31: 91-98.

15. Nakanishi T \& Tanable T. 1970. Studies on bacteria in cow's milk. Jap J Dairy Sci. 19: 144-150.

16. Foster E, Nelson FE, Speck ML, Doctch RN \& Olson JC Jr. 1979. Dairy Microbiology, p 275. Prentice Hall, Englewood Chiffs.

17. Pak T. 1995. Pasteurized milk products. In Dairy Processing Handbook, p 202. Lund, Sweden.

18. De S. 2005. Market milk. In Outlines of Dairy Technology, $19^{\text {th }}$ edn. Oxford University Press, Oxfoird.

19. Rogick FA \& Burgwold LH. 1952. Some factors which contribute to the psychrophillic bacterial count in market milk. J Milk Food Technol. 15: 181-185.

20. Macky H \& Erekson JA. 1941. Seasonal variation in thermoduric organisms and methods of control. Assoc Bull Inter. 6: 127-135.

21. Murry JG. 1949. The speed of build up of thermoduric organisms on farm equipment. Proc Soc Appl Bacteriol. 2: 20-25. 